Eur. J. Clin. Chem. Clin. Biochem.

Vol. 29, 1991, pp. 173-178

(C) 1991 Walter de Gruyter \& Co.

Berlin - New York

\title{
Assessment of Biological Reagents for Presence of Human Immunodeficiency Virus-1 (HIV-1) Antigens
}

\author{
By P. J. Howanitz, J. H. McBride and D. O. Rodgerson \\ Clinical Chemistry Laboratory, Department of Pathology and Laboratory Medicine, UCLA School of Medicine, \\ Los Angeles, CA, U.S.A.
}

(Received May 1/December 7, 1990)

\begin{abstract}
Summary: We tested 122 biological reagents including laboratory quality assurance sera and therapeutic human immune serum globulin products using an immunoenzymometric assay (IEMA) for HIV-1 antigens. Biological reagents tested were $64 \mathrm{HIV}-1$ antibody non-reactive and $44 \mathrm{HIV}-1$ antibody reactive quality assurance samples, and $14 \mathrm{HIV}-1$ antibody reactive human immune serum globulins from 21 manufacturers. Twenty-one of these biological reagents were previously reported by us as Western blot reactive.

All 122 samples tested were non-reactive for HIV-1 antigens. Low incidence of HIV-l antigen in these biological reagents should not alter laboratory safety practices in which all samples are considered infectious. Use of HIV-1 antigen measurements, either alone or with HIV-1 antibody determinations does not increase the likelihood of detecting HIV-l reactive samples.
\end{abstract}

\section{Introduction}

Although the acquired immunodeficiency syndrome (AIDS) was first reported in 1981, retrospective evaluation suggests that AIDS may have occurred in the United States almost 10 years earlier. In 1984, the causative agent was identified as a member of the human immunodeficiency virus family, HIV-1. More than 46000 individuals in the United States had developed AIDS by the end of 1987 (1), and concern for the widespread transmission of the disease persists. The clinical spectrum of infection is broad and includes an acute viral syndrome, asymptomatic carrier state, AIDS-related complex (ARC) and fulminant AIDS complicated by either Kaposi sarcoma, lymphoreticular malignancies, neurologic disorders, or opportunistic infections.

In 1985 the U.S. Food and Drug Administration (FDA) approved the first commercial reagents for measurement of antibodies to HIV-1 in human sera. Since that time, all human blood donor units have been tested and rejected for use if HIV-1 immunoenzymometric assay (IEMA) antibody results are posi- tive. Specimens which are repetitively IEMA reactive are subjected to Western blot analyses for confirmation. Also since 1985, manufacturers of quality control sera have begun testing source plasma and rejecting HIV-1 antibody reactive sera for quality assurance pools. However, human products for transfusion and injection, and quality assurance reagents produced before HIV-1 antibody testing still may be used for a number of years before expiration. In the United States, manufacturers routinely extend product shelf life on a yearly basis far beyond their original expiration dates.

Recent reports have indicated occupational risk of AIDS to health care workers and have prompted strengthened safety programmes (2). Whereas recipients of blood products have been at risk from treatment with infectious materials, laboratory workers may have been potentially exposed to HIV-l infected patients, to their sera, other body fluids, or tissues. Evidence of HIV-1 infection requires identification of specific serum IgG antibodies or isolation of virus from circulating peripheral blood lymphocytes, 
monocytes, or macrophages. Recent reports have indicated a high incidence of HIV-l antibodies in human serum-based quality assurance reagents and immune globulin preparations $(3-7)$, although no reports of individuals infected from these products have appeared.

In contrast, whole blood packed red cells, factor VIII, and cryo-preserved serum are among the products reported to frequently cause AIDS when transferred to non-infected humans. Procedures based on identification of HIV-l antibodies have been subject to interferences including non-specific antibodies to the $\mathrm{H}-9$ cell line from which viral antigens used in various assays were obtained (8), heating non-reactive sera $(9-11)$, and passive transfer of HIV-1 antibodies following treatment with human immune globulins (12). Viral isolation is time-consuming, expensive, and cannot be used for large numbers of specimens. Recently circulating HIV-1 antigen was detected in sera of infected individuals who developed specific HIV-1 antibodies (13). This antigen has also been found later during the course of infection in homosexuals, haemophiliacs, children born to sera positive mothers, and in high frequency in sera of individuals with AIDS.

The purpose of the present study was to investigate the prevalence of HIV-l antigens in quality assurance sera and immune serum globulin preparations classified as HIV-l antibody reactive and non-reactive. We also wanted to determine whether HIV-l antigen testing might be used alone or with HIV-l antibody testing to increase the likelihood of identifying HIV-l reactive sera.

\section{Materials and Methods}

Previously we tested and classified HIV-l antibody reactivity of quality assurance samples and human immune globulin preparations using the HTLV-III (HIV-l) IEMA test kit produced by Abbott Laboratories, North Chicago IL, 60064, U.S. A. (3, 5). We substantiated antibody reactivity of some samples by a second IEMA and Western blot analysis and subsequently tested 15 additional quality assurance samples by the same Abbott technique.

We then tested all human immune serum preparations and quality assurance samples with the Abbott HIV-I Ag IEMA test kit which uses polystyrene beads coated with human antibody to HIV-1. A $200 \mu \mathrm{l}$ sample or control was pipetted into wells of a reaction tray and then incubated with antibody coated beads. After incubation for $16-20 \mathrm{~h}$ at room temperature, excess sample was aspirated and the beads were washed. Next, $200 \mu \mathrm{l}$ of rabbit antibody to HIV-1 was added and incubated at $4{ }^{\circ} \mathrm{C}$ for $4 \mathrm{~h}$. Excess material was aspirated and beads were washed as before. Following addition of $200 \mu \mathrm{l}$ of goat antirabbit IgG conjugated to horseradish peroxidase and incubation at $4^{\circ} \mathrm{C}$ for $2 \mathrm{~h}$, the unbound material again was aspirated and the beads were washed. On addition of $300 \mu l$ of an orthophenylenediamine solution with hydrogen peroxide, the beads were incubated for $30 \mathrm{~min}$ at room temperature, and $1 \mathrm{ml}$ of $0.5 \mathrm{~mol} / \mathrm{l}$ sulphuric acid was added and the colour intensity read at $492 \mathrm{~nm}$ using a Quantum II analyser (Abbott
Laboratories). A sample was called reactive if its absorbance (A) was greater than, or equal to 0.05 plus the mean $A$ of three negative antigen controls.

We tested quality assurance reagents from the following sources:

American Dade, Miami, FL 33152;

American Monitor Corp., Indianapolis, IN 46268;

Beckman Instruments, Inc., Brea, CA 92621;

Behring Diagnostics, La Jolla, CA 92037;

Boehringer Mannheim Diagnostics, Inc., Indianapolis,

IN 46250;

Bio-Rad Laboratories, Richmond, CA 94802;

Clinical Chemistry Consultants, Temple City, CA 91780;

Fisher Scientific, Orangeburg, NY 10962;

Gamma Biologicals Inc., Houston, TX 77072;

Gilford Instrument Laboratories Inc., Irvine, CA 92714;

NMS Pharmaceuticals Inc., Newport Beach, CA 92663;

Ortho Diagnostic Systems, Raritan, NJ 08869;

Technicon Instruments Corp., Tarrytown, NY 10591.

We also tested in-house creatine kinase and cyclosporin quality control pools, derived from discarded serum from patients in our coronary care and transplant units.

Proficiency testing sera were obtained from the American Association for Clinical Chemistry, Washington, DC 20006; the American Society of Clinical Pathologists, Inc., Chicago, IL 60612; the College of American Pathologists, Skokie, IL 600771034; and the South Carolina Department of Health, Columbia, SC 29202. These commercial quality assurance reagent pools require up to 2000 donor units.

Fifteen human serum globulin preparations were tested. HBIG was from Abbott Laboratories, North Chicago, IL 80064; Hyperhep, Gamastan, Gamimune, HypRho-D and Hyper-Tet were from Cutter Biological, Emeryville, CA 94608; RhoGam was from Ortho Diagnostic Systems, Inc., Raritan, NJ 08869; and hyper immune globulin against Varicella-Zoster was from the American Red Cross, Washington, DC 20006.

\section{Results}

Table 1 lists 18 human-serum-based non-proficiency samples, 36 human serum-based proficiency samples and 11 bovine-serum-based non-proficiency samples which were non-reactive for HIV antibody as measured by the Abbott IEMA. Samples produced by Beckman and Clinical Chemistry Consultants were in a liquid matrix whereas all others were human lyophilized products. All 64 samples were non-reactive for HIV-l antigens.

Listed in table 2 are 24 non-proficiency samples and 20 proficiency samples which were HIV-1 antibody positive. The products listed are human-serum-based except those produced by Beckman. Fourteen had. been tested for Western blot reactivity and eight found reactive for at least $\mathrm{p} 24$. The 44 specimens were found non-reactive for HIV-l antigens.

Shown in table 3 are 14 human immune serum globulin preparations reactive for HIV-l antibody by the Abbott-IEMA. Three were Western blot positive (p24 and gp41), and eleven indeterminate (at least p24, p31 and p55), except for the Varicella-Zoster preparation (p55). The 14 human immune serum globulin preparations were negative for HIV 1 antigens. 
Tab. 1. HIV-l Antibody-negative samples.

\begin{tabular}{llllll}
\hline $\begin{array}{l}\text { Manufac- } \\
\text { turer/ } \\
\text { distributor }\end{array}$ & Use & Lot & $\begin{array}{l}\text { Manufac- } \\
\text { turcr/ } \\
\text { distributor }\end{array}$ & Use \\
\hline Human-serum-hased non-proficiency samples & & & \\
Amer. Mon. & General clinical chemistry & SH1035B & Dade & TDM & TDM2-215 \\
Dade & TDM & TDM3-315 & Dade & TDM & TDM2-315 \\
Beckman & General clinical chemistry & C403153 & Dade & General clinical chemistry & XLS-36A \\
Beckman & General clinical chemistry & C404172 & Fisher & Gencral clinical chemistry & 483-014 \\
Bio-Rad & TDM & 11301 & Fisher & Gencral clinical chemistry & 482-014 \\
Bio-Rad & TDM & 11302 & Gamma & Serology & KSL06E \\
Bio-Rad & TDM & 11303 & NMS & TDM & R06L-3A \\
BMC & General clinical chemistry & $3-370$ & NMS & TDM & R07M-3A \\
Dade & TDM & TDM1-115 & NMS & TDM & R08H-6A
\end{tabular}

Human-serum-based proficiency samples

\begin{tabular}{|c|c|c|c|c|c|}
\hline $\begin{array}{l}\text { AACC } \\
\text { AACC }\end{array}$ & $\begin{array}{l}\text { TDM } \\
\text { TDM }\end{array}$ & $\begin{array}{l}\text { March (1985) } \\
\text { April (1985) } \\
\text { Lyphocheck }\end{array}$ & $\begin{array}{l}\text { CAP } \\
\text { CAP }\end{array}$ & $\begin{array}{l}\text { Syphilis serology } \\
\text { Syphilis serology }\end{array}$ & $\begin{array}{l}\text { G-8 (1985) } \\
\text { G-10 (1985) }\end{array}$ \\
\hline ASCP & General clinical chemistry & CP 86 & CAP & Viral markers & W-12 (1985) \\
\hline CAP & General clinical chemistry & C-1 (1985) & CAP & Viral markers & W-13 (1985) \\
\hline CAP & General clinical chemistry & C-2 (1985) & CAP & Viral markers & W-15 (1985) \\
\hline CAP & General clinical chemistry & C-3 (1985) & CAP & Viral markers & W-16 (1985) \\
\hline CAP & Electrophoresis & S-6 (1985) & CAP & Viral markers & W-17 (1985) \\
\hline CAP & Electrophoresis & EC-2 (1985) & CAP & Viral markers & W-18 (1985) \\
\hline CAP & Electrophoresis & EC-5 (1985) & CAP & Viral markers & W-19 (1985) \\
\hline CAP & Electrophoresis & EC-6 (1985) & CAP & Viral markers & W-20 (1985) \\
\hline CAP & Electrophoresis & $\mathrm{EC}-12(1985)$ & CAP & General clinical chemistry & C-1 (1986) \\
\hline CAP & Serology & S-21 (1985) & CAP & General clinical chemistry & C-2 (1986) \\
\hline CAP & General clinical chemistry & C-4 (1985) & CAP & General clinical chemistry & C-5 (1986) \\
\hline CAP & General clinical chemistry & C-5 (1985) & CAP & Comprehensive & C-2 (1987) \\
\hline CAP & General clinical chemistry & C-6 (1985) & CAP & Ligand & K-1 (1987) \\
\hline CAP & General clinical chemistry & C-24 (1985) & CAP & Ligand & K-3 (1987) \\
\hline CAP & Syphilis serology & G-6 (1985) & CAP & Ligand & \\
\hline CAP & General clinical chemistry & G-7 (1985) & & & \\
\hline
\end{tabular}

Bovine-serum-based non-proficiency samples

$\begin{array}{lllll}\text { CCC } & \text { Enzyme } & 1-15-85 & \text { Dade } & \text { General clinical chemistry BSC2-203Z } \\ \text { CCC } & \text { Enzyme } & 334 \mathrm{~A}-84 & \text { Dade } & \text { General clinical chemistry BSC1-103Z } \\ \text { CCC } & \text { Acid phosphatase } & \text { Acid Phos. 17 } & \text { Dade } & \text { General clinical chemistry BSC1-103 } \\ \text { CCC } & \text { Carotene } & \text { Carotene 9 } & \text { Dade } & \text { General clinical chemistry BSC2-203 } \\ \text { CCC } & \text { Ammonia } & \text { Hi NH } 316 & \text { Technicon } & \text { General clinical chemistry B4F351H } \\ & & & \text { Technicon } & \text { General clinical chemistry BaF361K }\end{array}$

Non-standard abbreviations:

BMC - Boehringer Mannheim Diagnostics Inc.

CCC - Clinical Chemistry Consultants

AACC - American Association for Clinical Chemistry

ASCP - American Society of Clinical Pathologists

CAP - College of American Pathologists

TDM - Therapeutic drug monitoring

Liquid, ethylene glyçol-based samples: Beckman and CCC

\section{Discussion}

Shortly after infection with HIIV-l, viral antigens appear transiently in human sera followed by antibodies to viral envelope structural glycoprotein (gp41) and then the core structural proteins $\mathrm{p} 15, \mathrm{p} 18, \mathrm{p} 24$ and p55 (13). The disappearance of detectable HIV-1 antigen from the circulation is related to development of antibody to the core protein, p24. At this time infected individuals are asymptomatic carriers. The recurrence or persistence of viral antigen is associated with disappearance of antibody to p24 and correlates with clinical deterioration and progression to "fulminant" AIDS (15). Use of HIV-l Ag testing still does not identify individuals during the first few weeks of acute viral infection (13).

Procedures for testing blood products and biological reagents for clinical laboratories have required testing 
Tab. 2. HIV-l Antibody-positive samples.

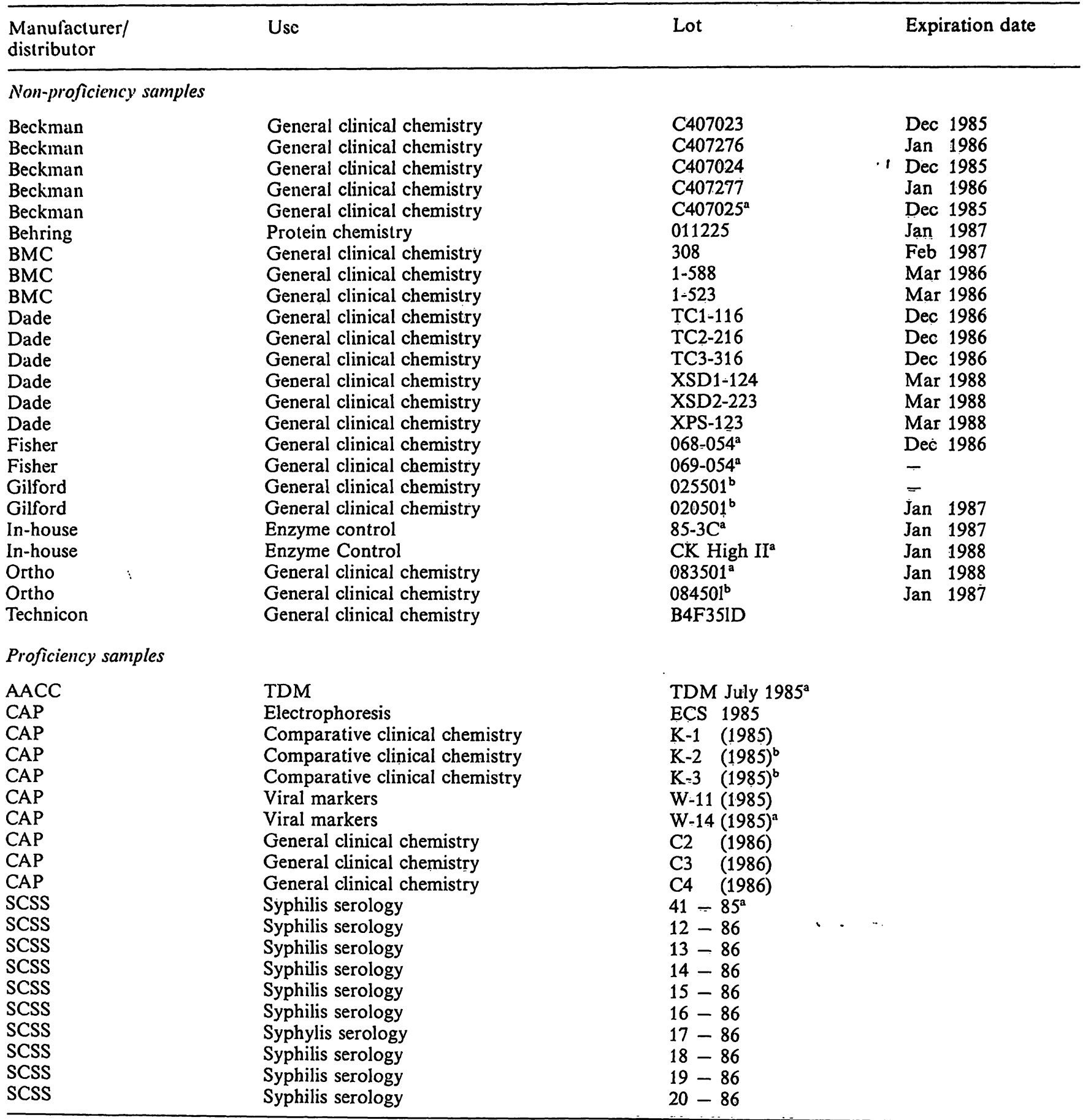

Non-standard abbreviations:

SCSS - South Carolina Syphilis Survey

TDM - Therapeutic drug monitoring

a - Western blot positive

b - Western blot negative

of donor sera for antibody to HIV-1 since 1985. Use of antigen testing may be of value in the identification of individuals who have been infected with HIV-l and who have not yet developed an antibody response. Detection of HIV-l antigen may also prove useful in monitoring patients for disease progression.

The Abbott HIV-1 Ag assay uses human polyclonal antibody reagent to viral core antigen p 24 and envelope antigen gp41. Assay analytical sensitivity is ap- proximately 30 to $40 \mathrm{ng} / \mathrm{l}$ for p24 and 200 to $300 \mathrm{ng} / \mathrm{l}$ for gp41. Average HIV-l Ag values in AIDS patients are approximately 100 to $500 \mathrm{ng} / \mathrm{l}$ with levels as high as $30 \mu \mathrm{g} / 1$ in some patients (14).

Our previous studies indicate that the prevalence of HIV-l antibodies in quality assurance sera or human immune globulin reagents was 31 and $100 \%$, respectively $(3,5)$, and approximates to the seropositivity in high risk groups. 


\section{Selenium in Medicine and Biology}

\section{Proceedings of the Second International Congress on Trace Elements in Medicine and Biology March 1988 - Avoriaz, France}

Editors Jean Nève, Alain Favier

1988. 17 x $24 \mathrm{~cm} . \mathrm{XX}, 428$ pages. Numerous illustrations. Hardcover DM 290,-; approx. US \$158.00 ISBN 3110117703

This book is a comprehensive and up-to-date review on the importance of selenium in human and animal nutrition. Starting from physiological aspects, it covers epidemiological and clinical data, giving detailed information on selenium requirements, supplementation and toxicity, and the methods for assessing selenium status. It includes contributions from famous experts and specialists in the field.

\section{From the Contents}

Selenium Intake, Metabolism and Homeostasis - Biological Functions of Selenium - Assessment of Selenium Status · Selenium in Human Diseases - Selenium Supplementation and Toxicity - Selenium in Animals - Author Index - Subject Index.

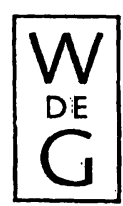
de Gruyter · Berlin • New York 


\section{Biochemistry of Peptide Antibiotics}

\section{Recent Advances in the Biotechnology of $\beta$-Lactams and Microbial Bioactive Peptides}

\section{Editors: Horst Kleinkauf, Hans von Döhren}

1990. $17 \mathrm{~cm} \times 24 \mathrm{~cm}$. XIV, 522 pages. With numerous illustrations. Hardcover. DM 310,-; approx. US \$ 182.00 ISBN 3110119285

Peptide Antibiotics, $\beta$-Lactams and bioactive Peptides have maintained a significant position in research and applications. Classical Cyclopeptides like Gramicidin S, Cyclosporin, Bleomycins, the various Proteinase Inhibitors, Siderophores, new $\beta$-Lactams and Vancomycin type Glycopeptides are presented from their representative leads in basic research in biosynthesis, genetics, chemistry, pharmacology, and biotechnology. The main developments of the last years have been reviewed, and structural information on naturally occurring Peptides has been compiled.

This monograph will serve researchers in the Peptide field as source and reference book.

\section{From the Contents}

Bioactive Peptides - Recent Advances and Trends - Gramicidin S Synthetase - Formation on $N$ methylated Peptide Bonds in Peptides and Peptidols · Peptide Bond Synthesis by Enzyme-Catalyzed Acyl-Transfer - Genetics of Siderophore Biosynthesis and Transport - Discovery of new $\beta$-Lactam and $\beta$-Lactam like Antibiotics from Bacteria - Glycopeptide Antibiotics of the Vancomycin Group - Peptide Phytotoxins from Plant Pathogenic Fungi - Chemical Synthesis and Bioactivity of Gramicidin S and Related Peptides - Cyclosporine: Synthetic Studies, StructureActivity Relationships, Biosynthesis and Mode of Action - Biosynthesis and Chemical Synthesis of Bleomycin - Small Molecular Protease Inhibitors and Their Biological Effects - Directed Biosynthesis of Neoviridogriseins - Biochemical Genetical and Biotechnical Aspects of Antibiotic Production via Immobilised Biocatalysis - Compilation of Peptide Structures - A Biogenetic Approach $\cdot$ Contributors $\cdot$ Index 
Tab. 3. HIV-1 Antibody-positive human immune serum globulin preparations.

\begin{tabular}{lll}
\hline Sample & $\begin{array}{l}\text { Immune } \\
\text { globulin for: }\end{array}$ & Lot \\
\hline $\begin{array}{l}\text { Hyperhep } \\
\text { Hyperhep }\end{array}$ & Hepatitis & (Cutter 16A06BB) \\
Gamastan & Hepatitis & (Cutter 160A04AC) \\
Gamastan & Hepatitis & (Cutter 15BOIB) \\
Gamastan & Hepatitis & (Cutter 15N05B) \\
Gamastan & Hepatitis & (Cutter 15N07A) \\
Gamastan & Hepatitis & (Cutter 150041-1) \\
Gamimune & Hepatitis & (Cutter 45 NII) \\
Gamimune & Hepatitis & (Cutter 45N16) \\
Hyper-Tet & Tetanus & (Cutter 14A05B) \\
HypRho-D & Rh & (Cutter 21A06A) \\
H-BIG & Hepatitis & (Abbott HIOlOOA) \\
RhoGam & Rh & (Ortho RHC600) \\
Varicella-Zoster & - & (Red Cross MVZIG-21) \\
\hline
\end{tabular}

The highest reported prevalence of HIV-l antibodies in high risk groups of haemophiliacs, intravenous drug users and homosexuals was 74,59 and $36 \%$, respectively (15). For that reason, it is surprising that none of the 122 human-based samples tested was reactive for HIV-1 antigen. Some of the 53 quality assurance samples which were non-reactive for HIV1 antibody may represent situations in which patients were antibody negative and if tested for antigen, would be reactive, thereby indicating an acute infection. However, no samples reactive only for HIV-1 Ag were found. This finding is similar to reports of screening of sera from 1000 blood donors for HIV-1 antigen reactivity and identifying no HIV-1 antigenpositive, antibody-negative sera (7).

Although 44 quality assurance samples and 15 intravenous globulin preparations were reactive for HIV1 antibodies, none was reactive for HIV-1 antigen. Three of the quality assurance samples and 14 human immune globulin reagents previously had been tested and found to be Western blot positive (presence of p24 and gp41). Recently, widely accepted criteria for Western blot positivity have been developed, and they include reactivity for any two of the following viral proteins: p24, gp41 and gp120/gp160 (16). This lack of antigen reactivity may indicate that sera for these reagents was obtained from donors during the carrier state when HIV-1 antigen is absent and antibodies are present. These findings are analogous to the report that when the HIV-1 antibody-reactive sera from 13 homosexual men supposedly in the carrier state were tested for HIV-l antigen, only one showed antigenaemia (17).

When serum specimens from individuals with fulminant AIDS are tested by Western blot technique they routinely have the gp41 antibody without the p24 antibody (15). However, 21 Western blot results of biological reagents previously reported by us had p24 reactivity without gp41 reactivity. When Western blot reactivity was studied using sera from a large group of patients with AIDS or at a high risk for AIDS, approximately $40 \%$ had gp 41 bands only (18). The sera used for our studies may have been obtained from a group of patients whose disease had not progressed to "fulminant" AIDS, but were asymptomatic carriers. It has been reported that individuals who are identified in high risk groups for AIDS voluntarily refrain from blood donation (18). A similar voluntary deferral may also occur in those individuals who are donors of sera for quality assurance reagents. Alternatively these individuals may be too ill with fulminant AIDS to consider sera donation. Because laboratory quality assurance reagents represent sera pooled from up to 2000 donors, another potential reason for antigen non-reactivity may be reaction of an antigen reactive unit with an antibody reactive unit thereby rendering antigen non-detectable.

The inability to culture HIV-1 from quality assurance reagents and lack of substantiated infectivity of human immune globulins support our findings that antigen was not detected in products tested (20). Recent reports have presented evidence that heating nonreactive specimens causes false positive results $(9-11)$, and sample treatment and handling by manufacturers of quality assurance reagents might have been responsible for similar results. In the survey by the College of American Pathologists (CAP) false positive results for HIV-I antibody tests were noted when quality assurance specimens were tested with reagents from one manufacturer (2). Although we used the same source of reagents for HIV-l antibody testing, it is doubtful that our antibody results represent false positive reactivity. We validated HIV-1 antibody assay results by demonstrating parallelism between positive samples tested and sera from patients with AIDS, verified some results with a second IEMA and Western blot procedures, and found appropriate controls non-reactive. Although haemophiliacs have developed AIDS after treatment with Factor VIII, the human immune globulins we tested had been subjected to Cohn fractionation, and it is possible that viral antigen present in these preparations may have been removed by this process.

Since our report that quality assurance sera contained HIV-l antibodies; manufacturers of these reagents have begun testing donors, and excluding those donors who demonstrate sera reactivity for HIV-l antibody. Sera used by the South Carolina Syphilis Survey programme has continued to react positively for HIV1 antibody in our hands. However, correspondence with the organizers of this programme indicates that 
this sera has been treated for $30 \mathrm{~min}$ at $56^{\circ} \mathrm{C}$ to inactivate live virus, and it is known that heating sera causes false positive HIV-I antibody results. Heating of sera does not alter HIV-1 Ag reactivity (22).

We postulate that sera from individuals with AIDS obtained for quality assurance reagents or human immune serum globulin preparations were obtained when donors were asymptomatic, and that HIV-I

\section{References}

1. Human immunodeficiency virus infection in the United States (1987) Morbidity Mortality Weekly Report 36, $801-$ 804.

2. Barnes. D. M. (1988) AIDS virus creates lab risk. Science 239, 348-349.

3. Howanitz, P. J., McBride, J. H., Kliewer, K. E. \& Rodgerson, D. O. (1986) Prevalence of antibodies to HTLV-III in quality control sera. Clin. Chem. 32, 773- 777.

4. Bove, J. R., DePalma, L. \& Weirich, F. (1987) Anti-HTLVIII/LAV in pooled sera. Clin. Chem. 33, 308.

5. Lai-Goldman, M., McBride, J. H., Howanitz, P. J., Rodgerson, D. O., Miles, J. \& Peter, J. B. (1987) Presence of HTLV-III antibodies in immune serum globulins preparations. Am. J. Clin. Pathol. 87, 635-639.

6. Gocke, D. J., Raskak, Jr., Pollack, W. \& Schwartzer, T. (1985) HTLV-III antibody in commercial immunoglobulin [Letter]. Lancet $I I, 1189$.

7. Steel, D. R. (1986) HTLV-III antibodies in human immune gamma globulin [Letter]. J. Amer. Med. Assoc. 255, 609.

8. Hunter, J. B. \& Menitore, J. E. (1985) HLA antibodies detected by ELISA HTLV-III antibody kits [Letter]. Lancet II, 397.

9. McBride, J. H., Howanitz, P. J., Rodgerson, D. O., Miles, J. \& Peter, J. B. (1987) Influence of specimen treatment on nonreactive HTLV-III sera. AIDS Res. Hum. Retroviruses $3,333-340$.

10. Jungkind, D. L., Renzosa, D. \& Young, S. J. (1986) Effect of using heat-inactivated serum with the Abbott human Tcell lymphotrophic virus type III antibody test. J. Clin. Microbiol. 23, 381-382.

11. Alexander, R. L. Jr. (1988) Heat inactivation of serum prior to measurement of HIV antibody by enzyme immunoassay. Clin. Chem. 34, 210-211.

12. Gordon, M. A. (1987) Caveat: False positive results of HIV testing [Letter]. Am. J. Clin. Pathol. 88, 542.

13. Allain, J. P., Laurian, Y., Paul, D. A. \& Senn, D. (1986) Serological markers in early stages of human immunodeficiency virus infection in haemophiliacs. Lancet $I I, 1233-$ 1236. antigen may have been removed from human immune serum globulins preparations during Cohn fractionation. Our findings that biological reagents tested in this study do not contain HIV-I antigen support other evidence that quality assurance reagents and human immune serum globulins do not contain viable virus. This should not deter clinical laboratories from safety practices in which all samples are considered infectious.

14. Goudsmit, J., Paul, D. A., Lange, J. M. A., Speelman, H., Van Der Noordaa, J., Van Der Helm, H. J., de Wolf, F., Epstein, L. G., Krone, W. J. A., Wolters, E. C., Oleske, J. M. \& Coutinho, R. A. (1986) Expression of immunodeficiency virus antigen (HIV-Ag) in serum and cerebrospinal fluid during acute and chronic infection. Lancet $I I, 177-$ 180.

15. van der Graaf, M. \& Diepersloot, R. J. A. (1986) Transmission of human immunodeficiency virus (HIV-III/LAV) A review. Infection $14,203-211$.

16. Centers for Disease Control. Interpretation and use of the Western blot assay for serodiagnosis of human immunodeficiency virus type 1 infections (1989) Morbidity Mortality Weekly Report 38, 1-7.

17. Lange, J. M. A., Paul, D. A., Huisman, H. G., de Wolf, F., van den Berg, H., Coutinho, R. A., Danner, S. A., van der Noordaa, J. \& Goudsmit, J. (1986) Persistent HIV antigenaemia and decline of HIV core antibodies associated with transition to AIDS. Brit. Med. J. 293, 1459-1462.

18. Resnick, L. \& Shapshak, P. (1987) Serologic characterization of human immunodeficiency virus infection by Western blot and radioimmunoprecipitation assays. Arch. Pathol. Lab. Med. 111, 1040-1044.

19. Kalish, R. I., Cable, R. G. \& Roberts, S. C. (1986) Voluntary deferral of blood donations and HTLV-III antibody positivity [Letter]. N. Engl. J. Med. 314, 1115-1116.

20. Lanier, D. (1986) Important product information update. Beckman Instruments, Inc. [Letter].

21. Centers for Disease Control, Update serologic testing for antibody to human immunodeficiency virus (1988) Morbidity Mortality Weekly Report 36, 833-840.

22. Sagona, M. A. Characteristics of the Abbott HIV Ag. Test (1987) Personal Communication.

James H. McBride, Ph. D.

Clinical Chemistry Laboratory

Dept. of Pathology

UCLA School of Medicine

10833 LeConte Ave.

Los Angeles, CA 90024-1713

U.S.A. 